\title{
地域メッシュ統計を利用した広域での非木造建築物群の震害予測 SEISMIC RISK MAPPING OF NON-WOODEN BUILDING IN LARGE AREA USING THE GRID-SQUARE STATISTICS
}

\author{
長谷川 浩一*, 翠川三 郎** \\ Kouichi HASEGA WA and Saburoh MIDORIKAWA
}

\begin{abstract}
As the basis for seismic microzoning on damage of non-wooden buildings, the spatial distribution of the population of non-wooden buildings should be evaluated. In this study, a procedure to estimate the population of non-wooden buildings with different construction age is proposed using the Grid-square Statistics. The vulnerability functions for different construction age are proposed using the damage survey data in Kobe area during the 1995 Hyogo-ken Nanbu, Japan earthquake. The proposed vulnerability functions are applied at five strong-motion stations in Kobe where the main shock records are available. The estimated damage rates agree with the observations. To evaluate seismic risk of non-wooden buildings, the damage ratios are estimated from the peak ground velocity computed for a hypothetical earthquake and the proposed vulnerability functions. Then estimated populations of non-wooden buildings and the damage ratios are integrated to obtain the number of damaged buildings. This procedure is applied in Tokyo and Kanagawa prefectures, and the building damage maps in the area are shown.
\end{abstract}

Keywords : Seismic microzoning, Non-wooden building, Vulnerability function, The Grid-square Statistics, GIS サイスミックマイクロゾーニング, 非木造建築物, 被害関数, 地域メッシュ統計, 地理情報システム

\section{1. はじめに}

地震により生じる各種構造物の被害を予測しておくことは地震 被害想定と呼ばれ，地域防災計画の基礎資料として重要な役割を 果たしている。この地震被害想定は，従来地方自治体によりそれ ぞれの行政区域に対して独立に行われてきた。しかし，地震の被 害は行政区域に関係なく生じるものであり，首都圈などの大都市 域では都市相互が非常に密接しているため，地震発生時には相互 の応援体制なども含めた総合的な地震防災対策が必要である。

地震被害想定の問題点として, 被害想定のための基礎デー夕を 整備するために多大な労力を要することや被害想定手法が自治体 によって異なることが，各自治体の防災担当者によって指摘され ている ${ }^{1)}$ 。また，各自治体が整備した自然環境や都市環境の情報 は限られており，一般に公開されていない。このような現状では， 既存のデータベースを利用し，行政区域を越えた広域の都市群を 対象として統一的に地震被害想定を提案することが，従来の地震 被害想定を補うための解決策の一つと考えられる。

著者らは，広域を対象とした地震被害想定手法として，既存の データベースを利用した木造建築物の震害予測手法を既に提案し ている(2)3)。多くの業務地域を抱える大都市圈においては，木造建 築物の他に $\mathrm{R} \mathrm{C}$ 造建築物などの非木造建築物が多く存在する。地 震が日中に発生した場合は，オフィスなど非木造建築物での人的
被害，物的被害，活動停止による間接被害など多大な被害が発生 することが予想されるため，大都市圏で非木造建築物の被害予測 を行っておくことは不可欠である。

非木造建築物の被害の程度は建築年代によって大きく差がある ことが, 兵庫県南部地震での被害調査結果から知られており4), 震害予測の精度を高めるために, 建築年代を考慮することが重要 と考えられる。本論文では, 非木造建築物群の建築年代別の棟数 分布の推定手法および兵庫県南部地震の被害調查結果に基づいた Vulnerability Function(以下, 被害関数と呼ぶ)を提案し, 想定地震 に対する非木造建築物の震害予測を行う手順を示す。

\section{2. 建築年代別の非木造建築物棟数の推定}

\section{1 地域メッシュ統計および利用した建築物GISデータ}

非木造建築物の棟数を推定するために，既存のデータベースで ある地域メッシュ統計 ${ }^{5)}$ を利用する。総務庁統計局によって編集 された地域メッシュ統計は, 国勢調査および事業所統計調査に基 づいている。メッシュの大きさは基準地域メッシュ(約 $1 \mathrm{~km}$ 四方 メッシュ)であり，人口集中地区(D.I.D)では 2 分の 1 地域メッ シュ(約500m四方メッシュ)である。国勢調査については昭和 45 年 から 5 年おきにのデータが, 事業所統計調查は昭和 50 年から約 5 年おきのデー夕がそれぞれ利用できる。
* 応用地質侏 GIS 事業部 博士 (工学) (研究当時東京工業大学大学院)

** 東京工業大学大学院総合理工学研究科 人間環境システム専攻 教授. 工博
GIS Business Division, Oyo Corporation, Dr. Eng.

Prof., Dept. of Built Environment, Interdisciplinary Graduate School of Science and Engineering, Tokyo Institute of Technology, Dr. Eng. 
国勢調查は, 人口, 世帯, 産業, 職業, 従業地・通学地, 人口 移動に関する調查項目からなるが，このうち，世帯についての デー夕には，住宅の建て方別世帯数という項目が含まれている。 昭和 55 年の調査では, 一戸建, 長屋建および共同住宅の 3 分類で あり，昭和60年以降では，共同住宅はさらに階数別(1-2F，3-5F， $6 \mathrm{~F}-)$ に分かれている。共同住宅の3 階建以上は，非木造が大半を 占めると考えられ，これらの世帯数から棟数を推定できる可能性 がある。

事業所統計調查は, 事業所の事業活動の状態を調査し, 事業所 の産業，従業者規模などの基本的構造を地域別に調查したもので ある。調查項目のうち，事業所数や従業者数は，事業所建築物の 棟数と関係があると思われる。また，開設時期別事業所数と開設 当時の事業所数から, 事業所の残存率が求められ, この值から事 業所建築物の残存率を推定できる可能性がある。

推定される棟数がどの程度の精度を持っているのかを確認する ために，実際の建築物 G I S デー夕を利用する。このデータは 1989年における川崎市の建築物の形状デー夕で，建築物一棟毎に 属性データとして用途，構造，階数が含まれているが，建築年代 の項目が含まれていない。そこで, 現存する建築物棟数の推定結 果との比較に利用する。建築年代別建築物棟数の推定結果の比較 には，東京都および川崎市の統計資料 ${ }^{617)}$ から得られる，自治体全 域での棟数の値を利用する。

\section{2 現存する非木造建築物棟数の推定}

非木造建築物は事業所建築物と中高層住宅が大半を占めると考 えられるので，それそれに対して現存する棟数の推定手法を示す。 2.2 .1 中高層住宅棟数の推定

平成 2 年国勢調查 ${ }^{8)}$ のうちの住宅の建て方別世帯数には，共同 住宅3-5階建，6階建以上が含まれている。これらの世帯数と昭和 63 年住宅統計調査 ${ }^{9}$ の共同住宅3-5階建，6階建以上の棟数を首都 圏の124の市区単位において比較した。この結果を図 1 (a)，(b) に示す。いずれの場合もややばらつきがみられ，世帯数だけでは 棟数を精度良く推定することができない。このばらつきは建物の 規模の地域的な特幑を反映しているものと考えられる。

建築物の規模は様々な影響を受けることが考えられるが，商 業・業務地域が発達した地域では広い數地の取得が困難であるな どの理由から，共同住宅の規模は小さくなることが推測される。 この地域特性を表す指標として居住人口に対する従業者数の比(以 下，従業者数/人口と呼ぶ)の值を利用することとした。従業者数 /人口の值は，商業・業務地域の占める割合が多い地域では大き な値をとり，住居系地域が多い地域では小さな值をとるものと考 えられる。

そこで, 従業者数/人口の值によって地域を分類したところ， 棟数と世帯数の関係は図 2 のような線形の傾向がみられた。例え ば，商業・業務地域に対応している従業者数／人口か 1 以上の地 域では，他の地域より回帰係数が大きく，中高層住宅 1 棟の規模 が小さいことがわかる。

川崎市の建築物 G I S データを利用して 2 分の 1 地域メッシュ 単位で世帯数と棟数との関係を調べたところ，6階建以上では市 区単位での回帰式と同様の傾向を示したので，6階建以上では市

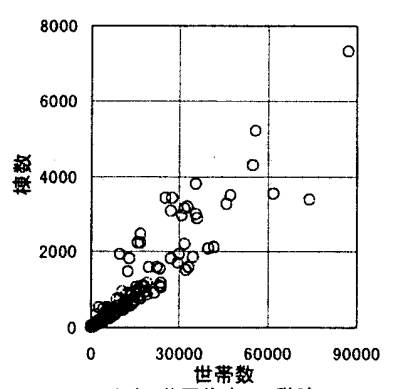

(a) 共同住宅3-5階建

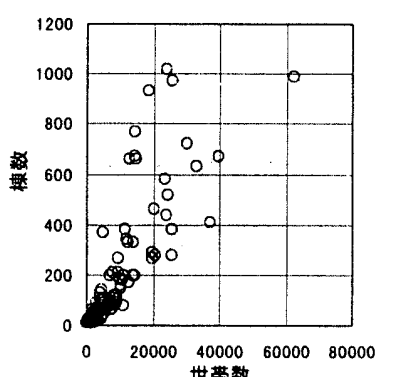

（b）并同住宅6階建以上
図1 首都圈市区単位での中高層共同住宅の世帯数と棟数の関倸

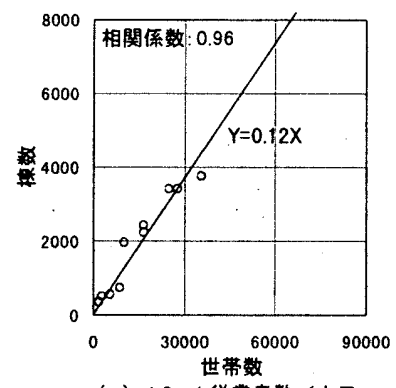

(a) $1.0=<$ 従菜者数 $/$ 人

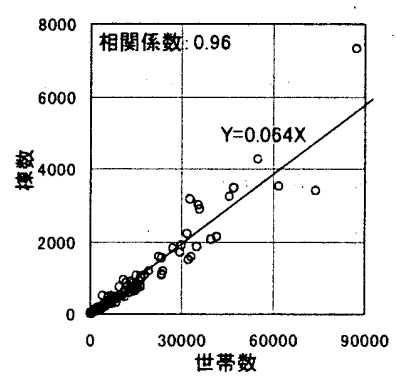

(c) $0.25=$ 従莱者数 $/$ 人 $<0.5$

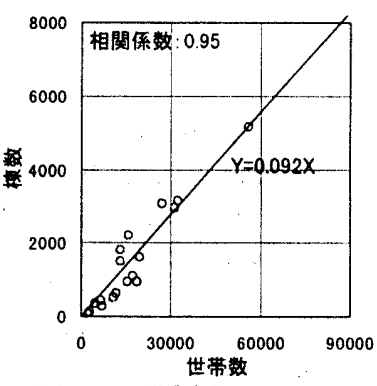

(b) $0.5=<$ 従菜者数 $/$ 人 $<1.0$

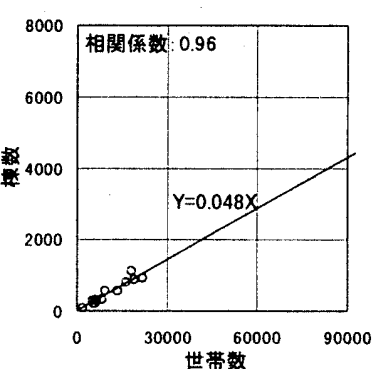

(d) 徉莱者数 /人口 $<0.25$
（1）3-5階建共同住宅の世帯数と楝数の関保
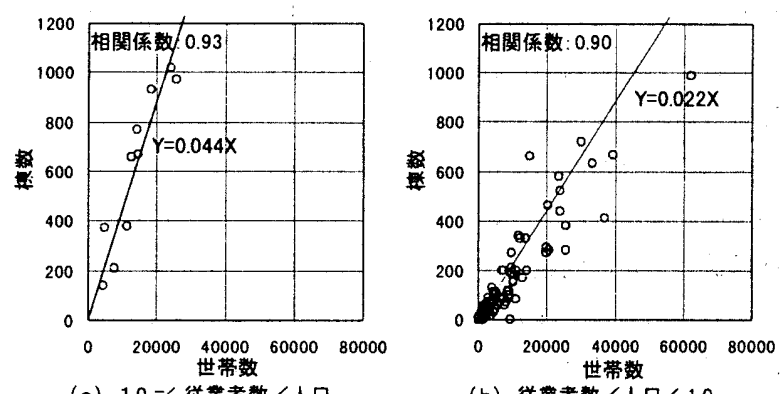

(a) $1.0=<$ 従莱者数 $/$ 入口

（2）6階建以上共同住宅の世需数之棟数の関保

図2 市区単位での中高層共同住宅の世帯数と棟数の関係

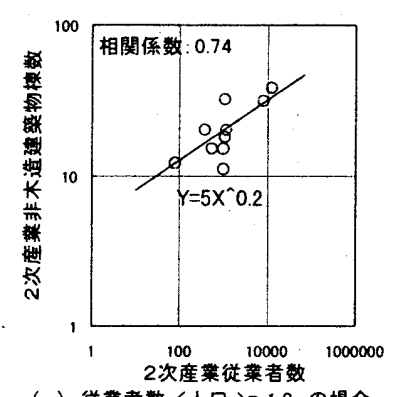

（a）従菜者数 $/$ 人 $\rangle=1.0$ の場合

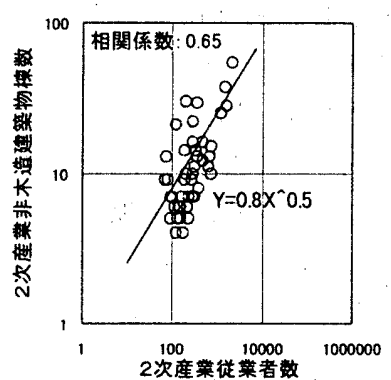

（b）従莱者数/人口く1.0の㺟合

図32次産業従業者数と2次産業非木造建築物棟数の関係 


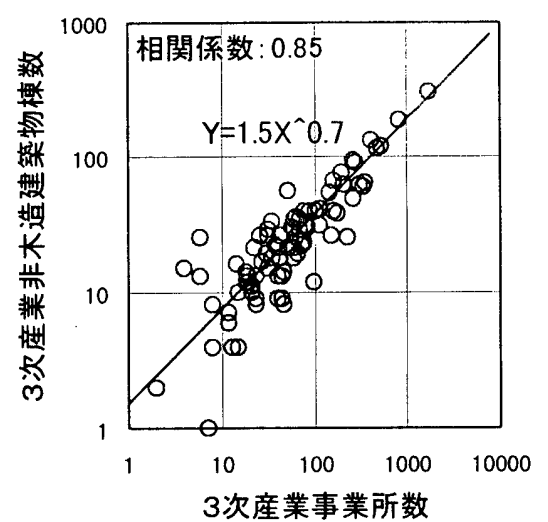

図43次産業事業所数々3次産業非木造建築物 棟数の関係
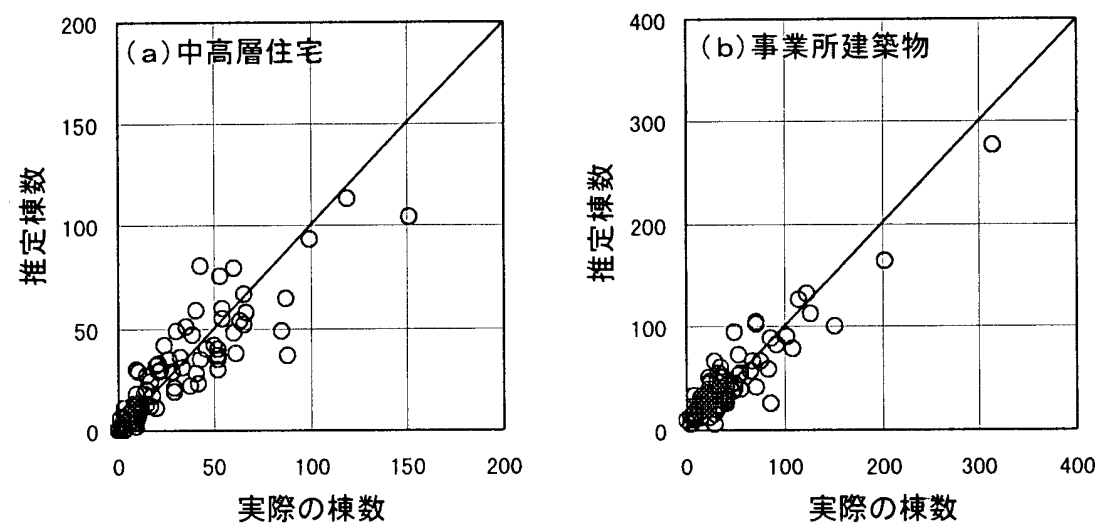

図5 現存する実際の非木造建築物棟数と推定棟数の比較

(a)中高層住宅, (b) 事業所建築物
区単位での結果を利用する。しかし，3-5階建では市区単位での回 帰式はやや過小評価となった。

これは，3-5階建住宅には共同住宅以外に店舗併用の一戸建住宅 が多く含まれているためと思われる。平成 5 年住宅統計調査 ${ }^{10)}$ おいて，非木造で 2 階建以上の店舗併用一戸建住宅を3-5階建一戸 建住宅とみなすと，3-5階建共同住宅に対する店舗併用一戸建住宅 の割合は，首都圏では3-5階建共同住宅の0.36倍であることから， 3-5階建共同住宅の回帰係数を1.36倍したものを3-5階建住宅の回 帰式とすることとした。ただし，この倍率は地域によってやや異 なり，例えば大阪府・兵庫県では1.6倍であるので，推定式(1)式 を首都圏以外で利用する場合には注意を要する。

この場合の分類別の回州式を(1)，(2)式に示す。ここで， $y_{1}$, $y_{2}$ はそれぞれ住宅3-5階建，6階建以上の棟数， $x_{1}, x_{2}$ はそれぞれ共 同住宅3-5階建，6階建以上の世帯数，rは従業者数/人口である。

$$
\begin{aligned}
& y_{1}= \begin{cases}0.17 x_{1} & (1.0 \leq \mathrm{r}) \\
0.13 x_{1} & (0.5 \leq \mathrm{r}<1.0) \\
0.087 x_{1} & (0.25 \leq r<0.5) \\
0.065 x_{1} & (r<0.25)\end{cases} \\
& y_{2}= \begin{cases}0.044 x_{2} & (1.0 \leq r) \\
0.022 x_{2} & (r<1.0)\end{cases}
\end{aligned}
$$

\section{2 .2 事業所建築物棟数の推定}

事業所建築物は，主に 2 次産業，3 次産業の事業所が入居して いる。事業所建築物の形態は産業によって異なることが予想され るので，事業所建築物を 2 次産業と 3 次産業に分類する。

川崎市のGISデー夕を用いて，2 次産業系の非木造建築物の棟数 と，地域メッシュ統計の事業所数および従業者数との相関を 2 分 の 1 地域メッシュ単位で検討したところ，2 次産業の事業所数よ り従業者数との相関が比較的良かった。そこで，従業者数を利用 することとしたが，ばらつきがそれほど小さくないので，従業者 数／人口で地域特性を考慮して検討したところ，図 $3(\mathrm{a})$, (b)の ような結果を得た。従業者数／人口が大きい分類(a)には，商業・ 業務地域または大規模工業地域が含まれており，前者では建築物 の規模が小さく，後者では規模が比較的大きいと推測される。そ
のため，棟数と従業者数の間に非線形の関係が生じたものと考え られる。また，分類(b)は住宅地ないし商業・住宅混合地域であり， 建築物の規模は小から中程度であると推測され，そのため, 分類 (a)と異なる関係が得られたものと考えられる。

3 次産業系非木造建築物についても 2 次産業と同様の検討を 行った。3 次産業の場合には，事業所数との相関の方が比較的良 かったので，3次産業事業所数をパラメー夕として棟数の推定を 行った。また，従業者数/人口による地域特性の分類も行ったが， 相関はほとんど向上しなかった。この結果を図 4 に示す。

以上の結果得られた 2 分の 1 地域メッシュ単位での回为式を棟 数の推定式とし，(3)，(4)式に示す。ここで， $y_{3} ， y_{4}$ は推定され る 2 次, 3 次産業系非木造建築物棟数， $x_{3}, x_{4}$ は 2 次産業従業者 数，3 次産業事業所数， $r$ は従業者数/人口である。

$$
\begin{gathered}
y_{3}= \begin{cases}5 x_{3}^{0.2} & (1.0 \leq r) \\
0.8 \sqrt{x_{3}} & (r<1.0)\end{cases} \\
y_{4}=1.5 x_{4}^{0.7}
\end{gathered}
$$

\section{2 .3 非木造建築物の実際の棟数と推定値の比較}

川崎市の平成元年での実際の非木造建築物棟数と, 推定式(1)か ら(4)式を地域メッシュ統計のうち平成2年国勢調查および平成 3 年事業所統計調查に適用して得られた非木造建築物の推定棟数を 比較した結果を図 5 に示す。両者は良い一致を示しており，提案 した推定式の妥当性を示している。

\subsection{0年以前の非木造建築物棟数の推定}

(1.)から (4)の推定式を利用して，ある年代における非木造建築 物棟数が推定できる。推定されたある年代での棟数に建築物の残 存率を掛け合わせて，建築年代別の棟数の推定を行った。建築年 代の区切りは，建築基準法の改正があった年である1980年とした。 この年以降に建てられた非木造建築物は兵庫県南部地震において 大きな被害は比較的軽微だったことが報告されている。同様に建 築基準法の改正のあった1971年も年代の区分として重要であるが， 昭和 45 年国勢調査には住宅の建て方別世帯数の項目がないことや, 
事業所統計調查は昭和 50 年以降のものしか利用可能でないことか ら，1971年で区分を行えなかった。

\section{3 .1 1980年時点での非木造建築物棟数の推定}

1980年時点での中高層住宅棟数推定のために地域メッシュ統計 デー夕を(1)，(2)式に適用する際，昭和55年国勢調查の共同住宅 の世帯数は, 階数別の分類となっでいないので，昭和 60 年国勢調 查での共同住宅の階数別の比率を昭和 55 年の共同住宅世帯数に乗 じた值を昭和 55 年での世帯数として利用した。事業所棟数推定の ためには，(3)，(4)式に，昭和56年事業所統計調査での従業者数， 事業所数を適用した。

\section{3 .2 中高層住宅の残存率}

著者らは以前に木造建築物の残存率の推定において，国勢調查 の入居時期別人口のデー夕を利用した ${ }^{2)}$ が, 中高層共同住宅の建 て替えは必ずしも人口の移動とは関係が無いと考えられるので， 同様の手法を適用することは困難であると考えられる。そこで， 住宅統計調查の東京都と神奈川県から得られる建築年代別住宅数 を利用して推定した。

昭和 63 年, 平成 5 年の住宅統計調查 ${ }^{9 / 10)}$ の中高層共同住宅の建 築年代別住宅数を比較して経年別に 5 年間での残存率を計算した 結果，経年が $0 \sim 15$ 年以上の住宅の各残存率はいずれも0.94前後 の値であったので，1980年から1995年までの間の残存率はこれら の値を 15 年分乗じて得られた値 0.84 を利用する。

\subsection{3 事業所建築物の残存率}

事業所建築物が滅失する場合，その建築物に入居している事業 所は他の地域へ転出するであろうことから，事業所が減少する割 合によ.り，事業所建築物の残存率を推定できる可能性がある。

そこで，事業所建築物の残存率の推定には，事業所統計調査の 開設時期別事業所数を゙利用する。平成 3 年事業所統計調査での開 設時期別事業所数は, 開設時期が昭和 30 年, 40年, 50 年, 60 年, 平成 2 年を区切りにした各時期毎に事業所数が得られている。こ のうち開設時期が昭和 59 年以前の事業所数 $N_{1}$ と昭和 56 年事業所統 計調查の事業所総数 $N_{2}$ を比較すると, $J=N_{1} / N_{2}$ の値が 1981 年から 1991年の間の近似的な事業所の残存率となる。

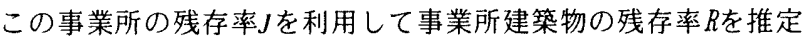
する。JとRの関係がどのようになっているのかを知るのに十分な データが無いため，ここでは，事業所の転出率(1-J)のうち半分の 割合が建築物の建て替えを伴い，事業所が残存する場合は建替え は行われないものと仮定して，事業所の残存率Jから事業所建築物 の残存率 $R$ 推定する式を(5)式のように考えた。

$$
R=J+0.5(1-J)
$$

$R$ は1981年から1991年の間の值であるので，1981年から1995年 までの推定残存率 $R_{1}$ にするためには，Rを1.5乗する。．(6)式に推 定残存率 $R_{1}$ を示す。

$$
R_{1}=R^{1.5}
$$

2.3.4 1995年での1980年以前の非木造建築物棟数の推定 棟数推定式(1)式から(4)式を用いて，あるメッシュでの昭和55
表1 1980年以前の非木造建築物棟数と推定棟数の比較

\begin{tabular}{|c|r|r|}
\hline 行政区域 & \multicolumn{1}{|c|}{ 実際の棟数 } & \multicolumn{1}{c|}{ 推定棟数 } \\
\hline 川崎市 & 17,823 & 20,283 \\
\hline 東京都 & 238,800 & 262,675 \\
\hline
\end{tabular}

年当時の3-5階建，6階建以上の中高層共同住宅および 2 次， 3 次 産業事業所建築物の推定值をそれぞれ $y_{1}^{\prime}, y_{2}^{\prime}, y_{3}^{\prime}, y_{4}^{\prime}$ とすると， 1995年での1981年以前の非木造建築物棟数の推定值 $Y^{\prime}$ は，(7)式 のように推定残存率と1980年当時の建築物棟数から計算される。

$$
Y^{\prime}=0.84\left(y_{1}^{\prime}+y_{2}^{\prime}\right)+R_{1}\left(y_{3}^{\prime}+y_{4}^{\prime}\right)
$$

川崎市および東京都の全域での実際の棟数 ${ }^{677)}$ と推定棟数を比較 した結果を表 1 に示す。ここでの実際の棟数は，いずれも軽量 $S$ 造 を除いた值である。川崎市，東京都ともに推定棟数は実際の棟数 とおおむね一致している。東京都および神奈川県北部地域での 1980年以前に建てられた非木造建築物の推定棟数の分布を図 6 に 示す。

\section{3. 非木造建築物の建築年代別被害関数の作成}

非木造建築物の震害予測を行うためには，非木造建築物に対す る被害関数が必要である。林・他 ${ }^{11}$ は，兵庫県南部地震での建設 省建築研究所がとりまとめた被害調査 ${ }^{12}$ ( 以下，被害調查 I と呼 ぶ)の被災度基準に基づいて，3階建以上の中高層建築物の被害関 数（以下，中高層被害関数と呼ぶ）を作成している。ただしここ の中高層被害関数は建築年代別には与えられていない。

一方，中央区，灘区および東灘区で行われたコンクリート系建 物の被害調查 ${ }^{4}$ ( 以下，被害調查 II と呼ぶ)では建物の被害と建築 年代が調查され，これに基づいた被害関数(以下， R C 被害関数と

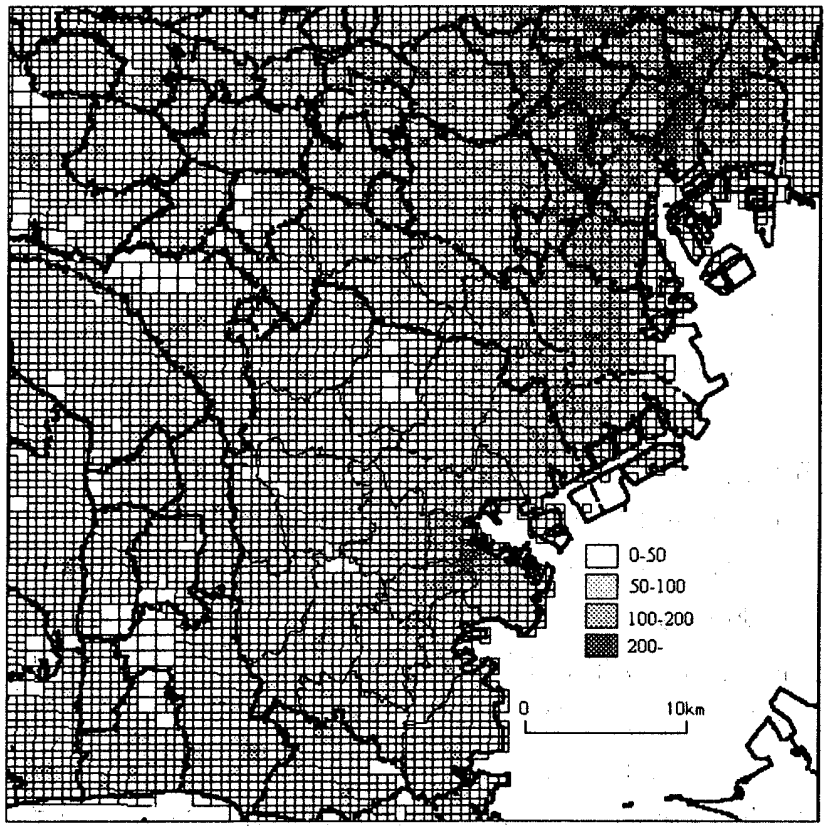

図6 東京都および神奈川県北部地域での1980年以前に建てられた 非木造建築物の推定棟数の分布 
呼ぶもも提案されている(3)。しかし，この調査の被害判定基準は被 害調査 Iのものとは異なり, また調査された被災度は全半壊のみ である。

本研究では，既に提案した木造建築物の被害予測手法との整合 性を考えると, 被害調查 I の被害判定基準に基づく被害関数を用 いることが望ましい。そこで，建築年代別の R C 被害関数を利用 して，被害調查 I に基づく中高層被害関数を建築年代別にするた めの換算を行った。なお，ここで提案する被害関数は異なる調查 結果をつなぎあわせて推定したもので，第一次近似的に作成され たものであり，より詳細なデータが利用できれば見直されるべき ものであろう。

\section{1 全年代の被害関数から建築年代別の被害関数への換算}

$\mathrm{RC}$ 被害関数では，1971年以前，1972から81年，1982年以降， および全年代に対して, 最大地動速度と被害率が(8)式に示される 標準正規分布関数で与えられている。

$$
R(V)=\frac{1}{\sqrt{2 \pi} \sigma} \int_{-\infty}^{y} e^{\left[\frac{\left.-\frac{\left(\log V^{-}-\log V_{0}\right)^{2}}{2 \sigma^{2}}\right]}{2 c^{2}}\right.} d\left(\log V^{\prime}\right)
$$

ここで，R(V)はある最大地動速度Vでの被害率， $\sigma$ は標準偏差， $\log V_{0}$ は被害率が $50 \%$ になるときの最大地動速度の対数值である。

$\mathrm{R} \mathrm{C}$ 被害関数の各年代での式と全年代での式を適用範囲である 最大速度 $50 \sim 150 \mathrm{~cm} / \mathrm{s}$ で比較すると，図７に示すように，ある地 動速度 $V$ での 1971 年以前の建物の被害率は最大地動速度 $0.8 V$ での 全年代の被害率におおむ水一致する。同様に，1972年から1981年 の建築物の最大地動速度Vでの被害率は，全年代の被害関数の 0.9 Vでの被害率と，1982年以降の建築物の被害率は全年代の被害 関数の 1.2 Vでの被害率と，おおむね一致する。

そこで，ほぼ同じ被害率を与える最大地動速度の比を用いて， 中高層被害関数を年代別のものにした。すなわち，全年代の中高 層被害関数の $V_{0}$ を約 0.8 倍, 約 0.9 倍, および1.2倍したものを, 1971年以前，1972年から1981年および1982年以降の中高層被害関 数のそれぞれの $V_{0}$ として与えることとした。このとき標準偏差は 全年代での値に固定させている。

\section{2 各被災度の建築年代別の被害関数}

3.1で作成された各年代別被害関数への換算率を，中高層被害関 数の全壊・大破率，中程度の損傷以上率，軽微な損傷以上率の各 関数に適用した。被害調査 I と被害調查 II の各被災度定義には違 いがある(3)ので，この換算は被災度基準がほぼ等しいもの同士で 行うべきであるが，R C 被害関数のもととなる被害調查 II は全半 壊のみ調查されており他に利用できる資料がなかったため，全て の被災度基準に全半壊での換算率を適用することとした。

本論文での非木造建築物の棟数推定の際に，建築物デー夕の制 約を受けて建築年代の区切りを1981年のみとしたので，被害関数 の建筑年代の区切りも同様に1981年とする必要がある。1981年以 前の被害関数のパラメータ $V_{0}$ は，1971年以前と1972-81年の関数の $V_{0}$ をそれぞれに対応する建築物の棟数の比率で加重平均した值と した。ここでは，建築年代別棟数を記した資料が見つからなかっ

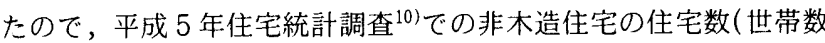
とほぼ同数)の比率を利用した。これによると，東京都と神奈川県 における非木造住宅の1970年以前の住宅数と1971-80年の住宅数
表2 非木造建築物の建築年代別被害関数のパラメー夕

\begin{tabular}{|c|c|c|c|c|c|}
\hline \multicolumn{3}{|c|}{$\begin{array}{c}\text { 中高層建築物の被害関数 } \\
(\text { 林·他 }\end{array}$} & \multicolumn{3}{|c|}{ 換算後の建築年代別被害関数 } \\
\hline 被災度 & $\log V_{0}$ & $\sigma$ & 年代 & $\log V_{0}$ & $\sigma$ \\
\hline \multirow[t]{2}{*}{ 全壊·大破 } & \multirow[t]{2}{*}{2.52} & \multirow[t]{2}{*}{0.355} & -1981 & 2.47 & 0.355 \\
\hline & & & $1982-$ & 2.60 & 0.355 \\
\hline \multirow{2}{*}{$\begin{array}{l}\text { 中程度の } \\
\text { 損傷以上 } \\
\end{array}$} & \multirow[t]{2}{*}{2.35} & \multirow[t]{2}{*}{0.359} & -1981 & 2.30 & 0.359 \\
\hline & & & $1982-$ & 2.43 & 0.359 \\
\hline \multirow{2}{*}{\begin{tabular}{|l|} 
軽微な \\
損傷以上
\end{tabular}} & \multirow[t]{2}{*}{2.07} & \multirow[t]{2}{*}{0.387} & -1981 & 2.02 & 0.387 \\
\hline & & & $1982-$ & 2.15 & 0.387 \\
\hline
\end{tabular}

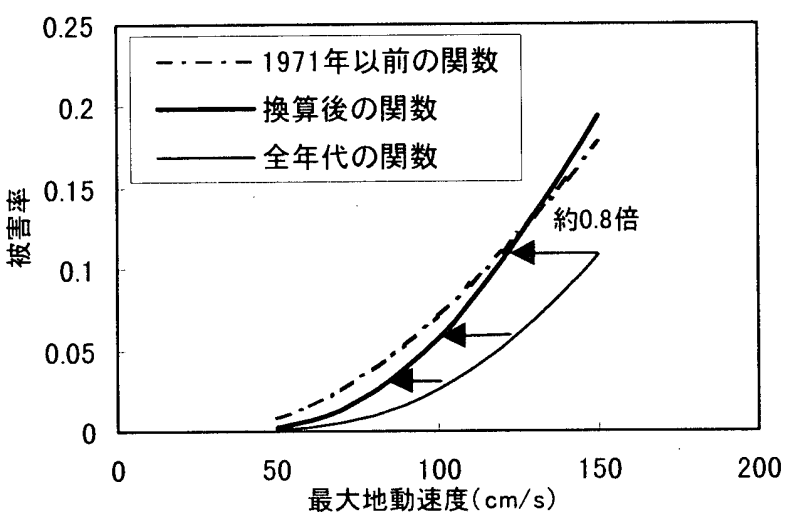

図7 全年代の関数から各年代別の関数への換算の例

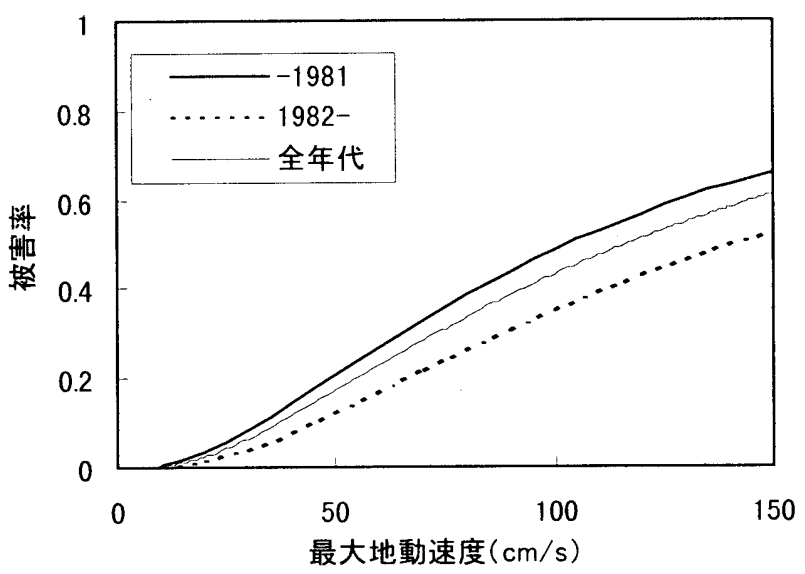

図8 作成された各年代別の被害関数(軽微な損傷以上)

の比はほぼ2：3であることより,この比を利用して平均値を求 めた。この換算結果を表 2 に，作成された被害関数のうち軽微な 損傷以上の関数を図 8 に示す。

\section{3 強震観測点周辺地域での被害率と推定值との比較}

作成された非木造建築物の被害関数の妥当性を確認するため, 神戸市内の強震観測点のうち地表面ないしそれに準ずる地点での 強震記録が得られている地点周辺での，調查結果 Iでの被害率と 推定值との比較を行った。比較に利用した観測点は, 本山第一小 学校 ${ }^{14)}$, 莫合 ${ }^{15)}$, 鷹取 ${ }^{15)}$, NTT神戸 ${ }^{16)}$ の 4 地点とした。これらの観 測点の位置は, 震度 7 の地域ないしその周辺に分布している。被 害率の算出に用いた地域は, 強震観測点から海岸線に平行な方向

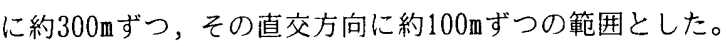


強震観測点周辺での建築年代1981年以前と1982年以降の棟数比 は，被害調查II の結果を利用して，本山第一小学校では，灘・東 灘区での R C 造建築物の比率 $1 ： 1$ ，咠合，NTT神戸および鷹取て は, 中央区での比率 $7: 3$ とした。鷹取は長田区にあるが建築年 代比を示す適当な資料がみあたらなかったので，中央区の比率で 代用した。

以上より，各強震観測地点での最大地動速度と非木造建築物の 被害関数から各被害率を算出し，建築年代比率で加重平均した推 定被害率と実際の被害率との比較を行った。各被害程度において， 多少のばらつきはあるものの両者はおおむね良い一致を示し，提 案した被害関数の妥当性を示している。各被害程度での比較結果 を図 9 に示す。

\section{4. 非木造建築物群の震害予測}

以上の結果を用いて想定地震に対する非木造建築物群の震害予 测を行った。想定地震として，横浜港の直下で震源哚さ $20 \mathrm{~km} ， マ$ グニチュード 7 の点震源を仮定し， 2 分の 1 地域メッシュ単位で の増幅度データと岩盤での最大速度振幅を乗じて地表面での最大

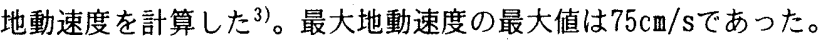

この最大地動速度分布と各建築年代での非木造建築物の被害関 数および各建築年代での非木造建築物棟数を用いて，2 分の 1 地 域メッシュ単位での建築年代別非木造建築物の震害予測を行った。 東京都および神奈川県北部地域での軽微な損傷以上を受ける非木 造建築物棟数の分布を図10に示す。木造建築物の被害の分布と異 なる傾向を示しており，非木造建築物が多く存在する都心部で被 害が大きくなることがわかる。推定を行った地域全体で軽微な損 傷の被害を受ける棟総数は約1.4万棟であり，木造建築物の被害棟 数約 5 万棟 ${ }^{3)}$ と比べてかなり少なくなっている。これは，存在す る非木造建築物の棟数が木造建築物に比べ少ないことと，同じ地 震動強さに対して非木造の被害関数が木造の被害関数より被害率 を小さく算出するためである。また，全壊・大破および中程度の 被害を受ける棟総数は，それそれ約 150 棟および約 1000 棟であっ た。ただし，ここでの震害評価には液状化の影響は考慮されてい ない。

\section{5. 結論}

本論文では，地域メッシュ統計を利用して非木造建築物棟数を 推定し，非木造建築物の建築年代別の被害関数を作成し，非木造 建築物の震害予測を行う手順を示した。以下にその結果を示す。

(1) 地域メッシュ統計のうち国勢調査および事業所統計調查に関 するデータを利用して，建築年代別の非木造建築物の棟数を 推定した。

（2）既往の非木造建築物の被害関数から非木造建築物の建築年代 別の被害関数を作成した。強震観測点 4 地点での最大地動速 度と本論文で提案した被害関数を用いて被害率を算出し，強 震観測点付近の実際の被害率を比較したところ，おおむね良 い一致を示した。

（3）地域メッシュ統計から建築年代別の非木造建築物棟数を推定 する手法，国土数值情報から最大地動速度を推定する手法お よび非木造建築物の建築年代別被害関数を利用して, 簡便に

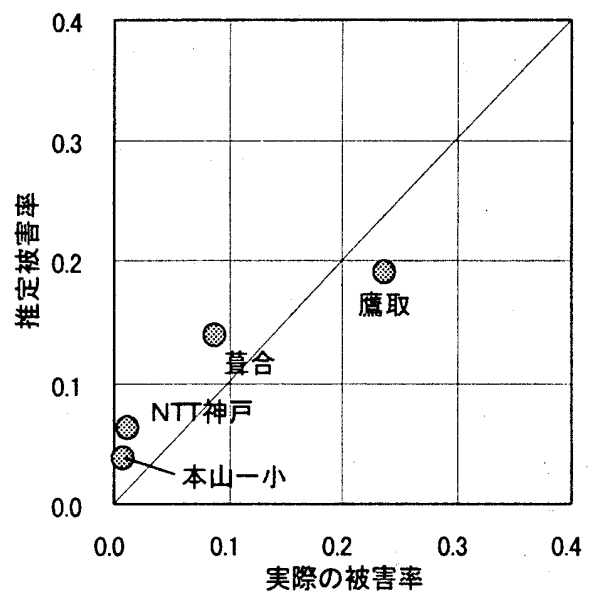

（a）全壊または大破率

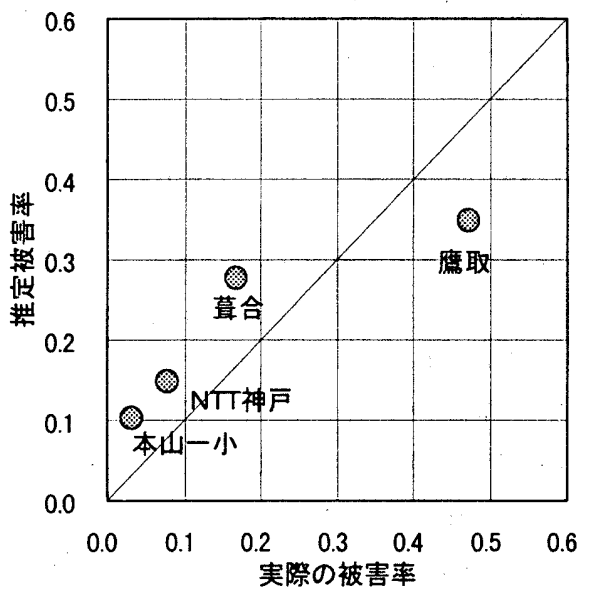

（b）中程度の損傷以上

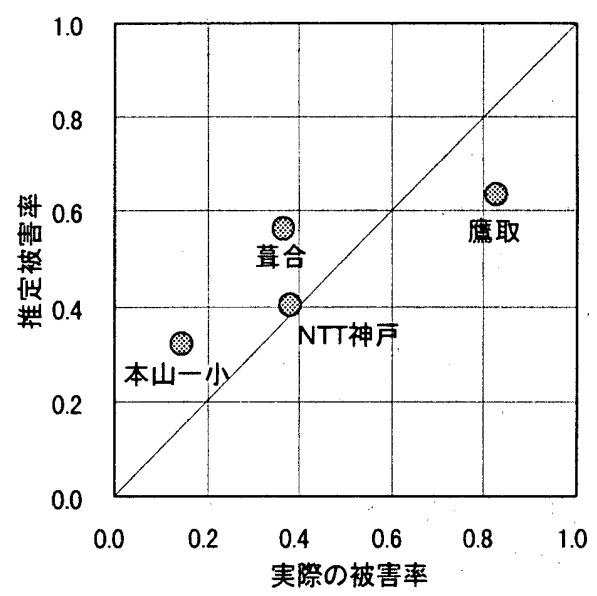

（c）軽微な損傷以上

図9 強震観測点付近での実際の被害率と推定値の比較

非木造建築物群の震害を予測する手順を示した。

なお，ここで提案した非木造建築物楝数を推定する手法は，首 都圏のデータに基づいて経験的に導いたものであることから，首 都圈以外の地域に適用する際には，何らかの実デー夕との比較に より，その適用性を確認した上で利用することが望ましい。

本研究では，建築学会近畿支部都市計画部会，日本都市計画学 


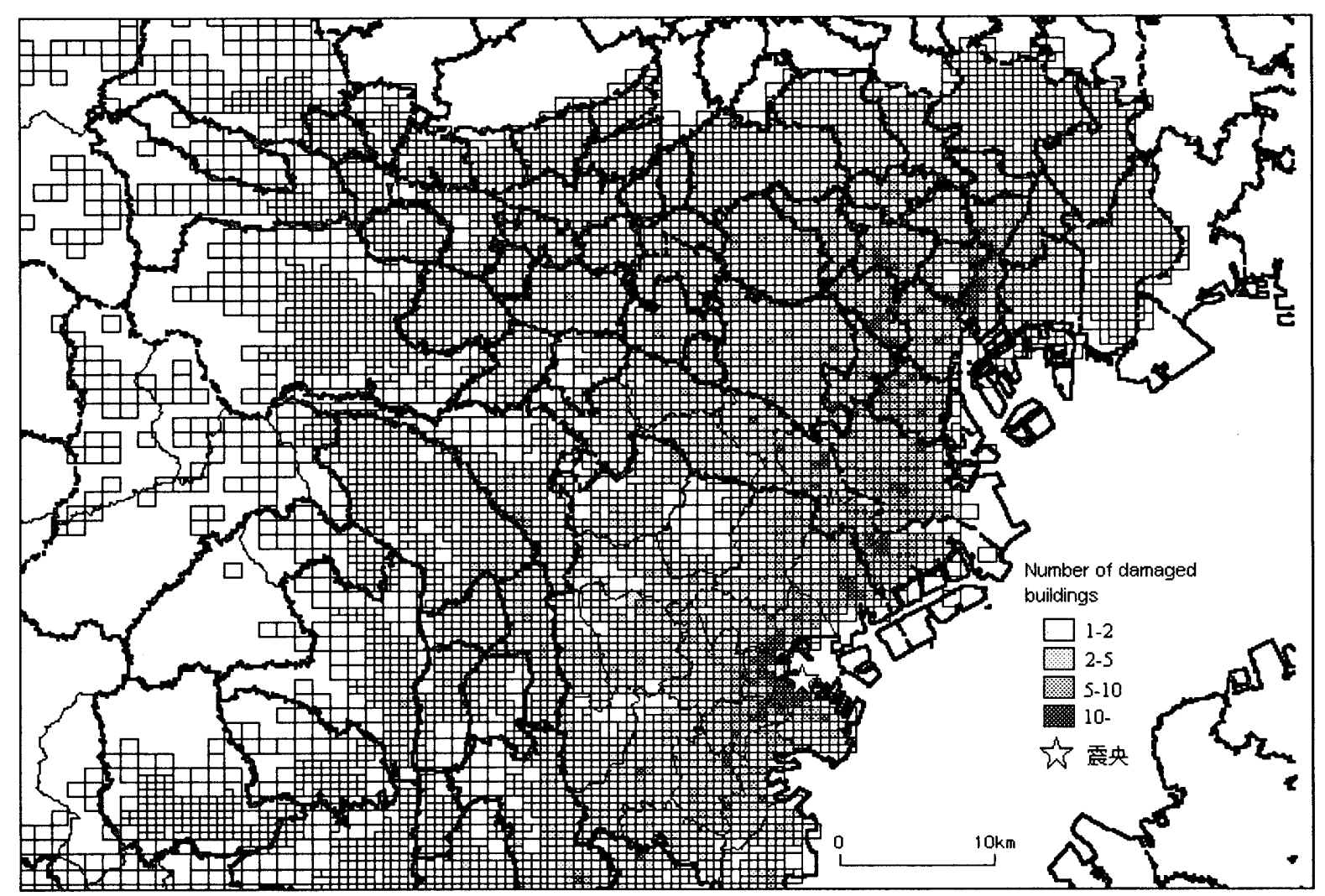

図10 東京都および神奈川県北部地域における想定地震で被害を受ける非木造建築物の推定棟数の分布

会関西支部および兵庫県都市住宅部計画課が建築物の被災度を調 査しそれを建設省建築研究所がまとめた被害調查結果と建築学会 近畿支部鉄筋コンクリート構造部会が調査した被害調查結果を利 用させていただきました。また，本研究で用いた強震記録は，関 西地震観測研究協議会，大阪ガス，鉄道総合技術研究所，N T T, 積水ハウスにより観測されたものです。記して感謝いたします。

\section{参考文献}

1）伊藤豊治：地震被害予測システムの現状及び今後のあり方, 地域安全学 会論文報告集，pp.62-65，1997.

2）長谷川浩一，翠川三郎：地域メッシュ統計を利用した木造建筑物群の震 害予测 一その1 建築年代別の木造建築物群の推定一, 日本建築学会 構造系論文報告集，No.497，pp.75-80，1997。

3）長谷川浩一，翠川三郎，松岡昌志：地域メッシュ統計を利用した木造建 築物群の震害予測 一その 2 建築年代別木造建築物の被害関数の作成 と震害予测例一, 日本建築学会構造系論文報告集, №. 505 , pp.53-59, 1998.

4）日本建築学会近畿支部鉄筋コンクリート構造部会：1995年兵庫県南部地 震コンクリート系建物被害調查報告書，1996。

5) 総務庁統計局：地域メッシュ統計の概要, 財団法人日本統計協会, 1994.

6) 東京都: 第47回東京都統計年鑑, 1996 .

7）川崎市：川崎市地震被害想定調查報告書，1997.

8）総務庁統計局: 平成 2 年国勢調查報告都道府県編，財団法人日本統計協 会, 1992 .

9）総務庁統計局：昭和63年住宅統計調查報告都道府県編，財団法人日本統 計協会, 1990 .

10）総務庁統計局：平成 5 年住宅統計調査報告都道府県編，財団法人日本統 計協会, 1995 .

11）林康裕，宮腰淳一，田村和夫，渡辺宏一：兵庫県南部地震の建築物被害 に基づく地震動強さの評価, 第 1 回都市直下地震災害総合シンポジウム 講演集, pp. $89-92,1996$.

12）建設省建築研究所：平成 7 年兵庫県南部地震被害調查最終報告書, 1996 .

13）宮越淳一，林康裕，田村和夫：1995年兵庫県南部地震の建物被害デー夕 に基づく被害関数の構筑，日本建築学会大会学術講演梗概集，B-2， pp.111-112, 1997.

14) T.Kagawa, K.Irikura and I.Yokoi:Restoring Clipped Records of Near Field Strong Ground Motion during the 1995 Hyogo-ken Nanbu(Kobe), Japan Earthquake, Journal of Natural Disaster Science, Vol.18, No.1, pp.43-57, 1996.
15）日本建築学会兵庫県南部地震特別研究委員会：1995年兵庫県南部地震強 震記録資料集, 日本建築学会, 1996 .

16）奥田堅持，赤木久畺，土肥博，二宮利文，翠川三郎，松岡昌志：兵庫県 南部地䨩におけるNT T 建物の地震記録について（その3）一常時微動 による神戸駅前ビルの震動特性及び地表面波の推定一, 日本建築学会大 会学術講演梗概集 B-2，pp.547-548，1996。

(1998年 9 月 7 日原稿受理， 1999年 1 月 28 日採用決定） 